\title{
EXPRESSION OF TLR2 AND TLR4 IN LESIONS OF PATIENTS WITH TEGUMENTARY AMERICAN LEISHMANIASIS
}

Felipe Francisco TUON(1), Elaine Ribeiro FERNANDES(2), Maria Irma Seixas DUARTE(2) \& Valdir Sabbaga AMATO(3)

\begin{abstract}
SUMMARY
Objectives: The aim of this study was to describe the pattern of expression of Toll-like receptor 2 (TLR2) and Toll-like receptor 4 (TLR4) in skin biopsies of patients with American tegumentary leishmaniasis (ATL) caused by Leishmania braziliensis. Methods: This prospective study evaluated 12 patients with ATL caused by Leishmania braziliensis confirmed by polymerase chain reaction. Immunohistochemistry was performed to determine the expression of TLR2 and TLR4. The number of NK cells, dendritic cells and macrophages in the tissue were calculated. The cytokine expression was determined using the anti-TNF- $\alpha$, anti-IFN- $\gamma$, anti-IL-1 and anti-IL-6. Double immunostaining reactions were used to determine the cell expressing TLR2 and TLR4. Results: The numbers of cells expressing TLR2 and TLR4 were $145.48 \pm 82.46$ cell $/ \mathrm{mm}^{2}$ and $3.26 \pm 4.11 \mathrm{cell} / \mathrm{mm}^{2}$ respectively $(p<0.05)$. There was no correlation of TLR2 and TLR4 with the amount of cytokines and the number of NK cells, dendritic cells or macrophages. The double immunostaining revealed that TLR2 was expressed by macrophages. Conclusion: In human cutaneous leishmaniasis caused by Leishmania braziliensis, TLR2 is the most common TLR expressed during active disease, mainly by macrophages although without correlation with the amount of cytokines and number of cells.
\end{abstract}

KEYWORDS: American tegumentary leishmaniasis; Leishmaniasis; Leishmania; Toll-like receptors; Immune response; TLR2; TLR4.

\section{INTRODUCTION}

Tegumentary leishmaniasis continues to be a problem in underdeveloped countries and is a continuous worry in developed countries due to the possibility of the disease afflicting tourists returning from countries where the parasite is endemic ${ }^{16}$.

Despite its increasing global incidence, leishmaniasis has become a neglected disease with little interest by financial donors, public health authorities, and professionals to implement activities to research, prevent, or control the disease $\mathrm{e}^{17}$.

Several immunological studies have increased our understanding of the adaptive response in American tegumentary leishmaniasis (ATL). Thus, this disease has been used as a model of Th1 and Th2 responses. Unfortunately, there are still several aspects of the initial steps of Leishmania spp. infection in humans that are largely unknown.

The Toll-like receptor (TLR) signaling pathway is one of the first defensive systems against Leishmania spp. ${ }^{18}$. After recognition of specific antigens, TLRs trigger NF- $\kappa \mathrm{B}$, which then proceeds to the nucleus and promotes the transcription and further synthesis of pro-inflammatory cytokines ${ }^{3}$.
Recent studies revealed that TLR2 and TLR4 contribute to the recognition of Leishmania major and to the subsequent immune response $e^{4,8,15}$. Nevertheless, discrepancy in TLR signaling has been observed when in vitro and in vivo studies have been published ${ }^{2,10-13}$.

All these previous studies were performed under ideal conditions using animal models or cell culture. We studied the expression of TLRs in the keratinocytes, but their importance in the dermis, where the inflammatory infiltrate occurs, is unknown ${ }^{21}$. We know that the development of new drugs, vaccines, diagnostic tests and prognostic perspectives are related to the knowledge of the immune response. Considering these facts, it is important to determine the cell of the immune response that expresses TLRs as well as the relationship of these receptors with other cells and cytokine production.

The aim of this study was to describe the pattern of expression of TLR2 and TLR4 in ATL caused by Leishmania braziliensis. Secondary objectives were to determine the cells involved in the expression of TLR and to perform a correlation between TLR and cytokine expression.

\section{METHODS}

1. Area of study: This prospective study evaluated 100 Brazilian

(1) Department of Infectious Diseases, Faculdade de Medicina da Universidade de Sao Paulo. Av. Dr. Enéas de Carvalho Aguiar 470, 05403-000 São Paulo, SP, Brazil.

(2) Laboratory of the Discipline of Pathology of Transmissible Diseases, Faculdade de Medicina da Universidade de Sao Paulo, Av. Dr. Arnaldo 455, 01246-000 Sao Paulo, SP, Brazil.

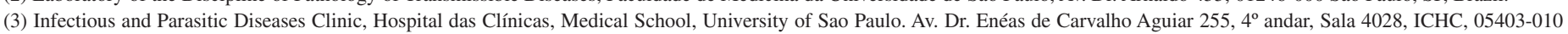
São Paulo, SP, Brazil.

This study was totally supported by FAPESP (Fundação de Amparo à Pesquisa do Estado de São Paulo).

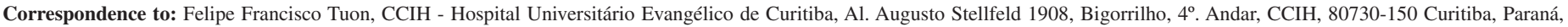
Brasil. Tel.: 55-41-3240-5000. E-mail: flptuon@gmail.com 


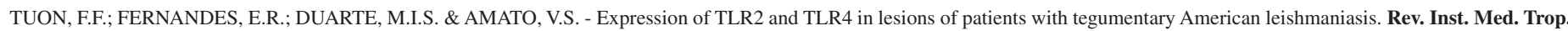
Sao Paulo, 54(3): 159-63, 2012.

patients with ATL from the Amazon region (Santarem City) from January 2002 to January 2003 . This city is localized at latitude $2^{\circ} 26^{\prime} 6.64 " \mathrm{~S}$ and longitude $54^{\circ} 42^{\prime} 4.04^{\prime \prime} \mathrm{W}$. The area of study is $36 \mathrm{~m}$, the climate is hot and moist, with a temperature range between $25^{\circ} \mathrm{C}$ and $28^{\circ} \mathrm{C}$.

Patients with confirmed diagnosis of ATL were included in the study. After informed consent, all patients were submitted to cutaneous scraping from the lesion, the Montenegro test, and skin biopsy. Clinical diagnosis of ATL was determined as previously described ${ }^{19}$. We included only patients with all the following findings: 1) amastigotes present on cutaneous scraping; 2) positive Montenegro's skin test; 3) immunohistochemistry showing Leishmania antigens; 4) Leishmania braziliensis confirmed by polymerase chain reaction (PCR). We included only skin biopsies with representative material, presence of epidermis and dermis, enough area to perform quantitative analysis. A control group with normal skin biopsy from patients without cutaneous disease was included for statistical analysis.

This study was approved by the Ethics Board of the School of Medicine (CAPPesq da Diretoria Clínica do Hospital das Clínicas e da Faculdade de Medicina da Universidade de São Paulo - No. 0913/07).

2. Laboratory tests: Montenegro's skin test was performed with intradermal injection of leishmanina (L. (L.) amazonensis - OMS MHOM/ BR/73/M2269 - CPPI, Piraquara, PR, Brazil), and the size of the skin response was measured after 48 hours. The diameter of induration was measured in millimeters.

Immunohistochemistry for detection of Leishmania antigens was performed as described previously using antibodies from Leishmania chagasi (a gift from Heitor Andrade Jr. from Instituto de Medicina Tropical, Brazil) ${ }^{1}$. The method is described in the section immunohistochemistry below.

3. Polymerase chain reaction for L. (V.) braziliensis: Samples from skin biopsies obtained from the borders of the lesions were used for PCR. The materials were stored in a buffered solution containing $150 \mathrm{mM} \mathrm{NaCl}, 50 \mathrm{mM}$ EDTA, and $100 \mathrm{mM}$ Tris at $\mathrm{pH}$ 7.5. DNA was obtained from the material following a previously described protocol ${ }^{5}$. Briefly, PCR to identify Leishmania (V.) braziliensis was applied to the DNA samples using a sequence of glucose-6-phosphate dehydrogenase. The first amplification is performed to detect the presence of DNA from subgenera Viannia, using the primers ISVC 5' (ATC-ACA-ATG-ATGGTC-AAC-GCA) and ISVA 5'(GTC-GGT-TAT-CCT-ATT-CGG-GTC). About 20 ng of sample DNA was used as a template in the first PCR assay, which was performed in a final volume of $50 \mu \mathrm{L}$ in $1 \mathrm{x}$ PCR buffer, $2 \mathrm{mM}$ $\mathrm{MgCl} 2,0.2 \mathrm{mM}$ dNTPs, $0.2 \mu \mathrm{M}$ of each primer (ISVC 5' and ISVA 5'), and $2 \mathrm{U}$ Taq DNA polymerase. The DNA was denatured at $94{ }^{\circ} \mathrm{C}$ for three min, followed by 35 cycles of $94{ }^{\circ} \mathrm{C}$ for one min, $50{ }^{\circ} \mathrm{C}$ for one min, and $72{ }^{\circ} \mathrm{C}$ for one min. A final extension at $72{ }^{\circ} \mathrm{C}$ was performed for seven min. A 1:100 dilution of this product was then subjected to nested PCR using the primers ISVC 5' (ATC-ACA-ATG-ATG-GTC-AAC-GCA) and ISVB 5' (TAC-TCG-CCA-TGT-CGG-AGG). The PCR products were analyzed by agarose gel electrophoresis ( $2 \%$, TAE buffer).

4. Immunohistochemistry: Cutaneous sections prepared from paraffin-embedded biopsies were cut into $5 \mu \mathrm{m}$ sections and mounted on glass slides. The slides were deparaffinized and incubated for $30 \mathrm{~min}$ with
Tris-buffered saline (TBS), Tween20 w/v (Sigma, St Louis, USA), bovine serum albumin (BSA) $0.1 \%$ (Sigma, St Louis, USA). They were then incubated for $30 \mathrm{~min}$ with the rabbit anti-TLR2 (AMS Biotechnology, Abington, UK, cod. AP1502) or the goat anti-TLR4 antibodies (SANTA CRUZ, Santa Cruz, USA, cod. SC10741)

One slide was incubated without primary antibody and constituted a negative control for TLR2 and TLR4. The specific antigen-antibody reaction was detected with a streptavidin-biotin-peroxidase-based system according to the manufacturer's instructions (LSAB ${ }^{\circledR}+$ system-HRP, DakoCytomation, Carpenteria, CA, USA).

Cellular phenotype was determined as described above, using the following mouse antibodies: anti-CD68 for macrophages (DAKO, Glostrup, Denmark, cod. M876), anti-CD57 for NK cells (LABVISION, Fremont, USA, cod. MS136P), and anti-CD1a for dendritic cells (SEROTEC, Oxford, UK, cod. MCA1657). Positive control with lymph nodes was used.

Cytokine expression was determined as described above, using the following antibodies: goat anti-TNF- $\alpha$ (R\&D, Minneapolis, USA, cod. AF20NA), mouse anti-IFN- $\gamma$ (R\&D, Minneapolis, USA, cod. MAB285), anti-IL-1 (R\&D, Minneapolis, USA, cod. AF215NA) and goat anti-IL-6 (R\&D, Minneapolis, USA, cod. AF206NA) in BSA 1\%, over night at $4{ }^{\circ} \mathrm{C}$. Positive control with lymph nodes was used.

For double immunostaining reactions, the slides were incubated overnight at $4{ }^{\circ} \mathrm{C}$ in the presence of anti-CD68 antibody or anti-CD57 or anti-CD1a as described above. The reactions were visualized using the 3,3'-diaminobenzidine (DAB) chromogen as before. After washing with phosphate buffered saline ( $\mathrm{pH} 7.4$ ), the slides were incubated overnight at $4{ }^{\circ} \mathrm{C}$ in the presence of anti-TLR 2 or anti-TLR 4 antibodies followed by incubation with Envision alkaline phosphatase (DakoCytomation, Carpinteria, CA, USA) for 30 minutes at $37{ }^{\circ} \mathrm{C}$. The reactions were visualized using Liquid Permanent Red (DakoCytomation, Carpinteria, CA, USA) and counterstained with Harris hematoxylin.

5. Quantitative analysis: For each specimen, cells were quantified by counting the number of immunolabeled cells in nine randomized highpower fields considering three levels of depth in the dermis. A x10 ocular lens was used with a square grid in a $\mathrm{x} 40$ objective marking an area field of $0.0625 \mathrm{~mm}^{2}$. This method has been used in previous studies $\mathrm{s}^{7,20,23,24}$.

6. Statistical analysis: Data were expressed as median with range or mean with standard deviation. Statistical analysis was performed by Graph Pad Prism version 4.0 for Windows (Graph Pad software, San Diego, CA) using the non-parametric Kruskal-Wallis test for larger group comparison, with Dunn post for individual groups and Mann-Whitney tests for two sample comparisons. Samples were considered different at the $95 \%(p \leq 0.05)$ level of significance.

\section{RESULTS}

1. Patients selection: From 100 patients, 16 had negative Montenegro skin test; 25 cases without amastigotes on cutaneous scraping; immunohistochemistry without Leishmania antigens in 19 cases; 10 patients with other species than Leishmania braziliensis. Eighteen biopsies were discharged because insufficient epidermis or material for 

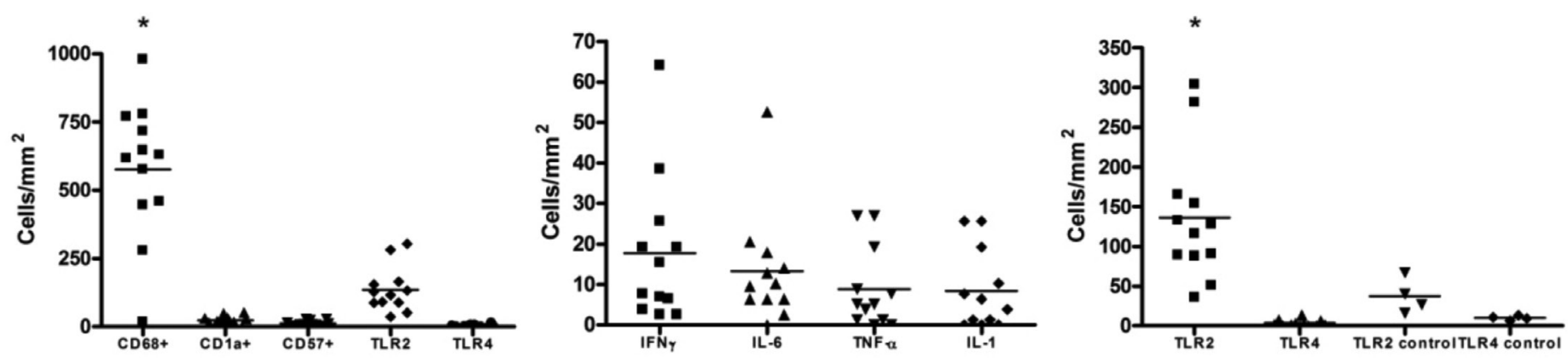

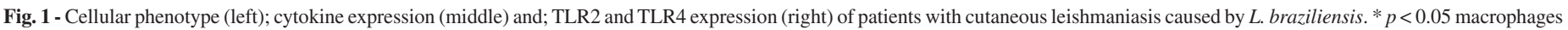
vs. other cells and TLRs expression. In the right graph, TLR2 and TLR4 expression is compared with a control group.

sections. Considering the inclusion criteria described above, only 12 cases were eligible for the evaluation of TLRs.

All 12 patients were male with a median age of 22 [16 - 46] years. The median duration of disease before biopsy was 90 [30 - 120] days and all lesions were localized in the lower limbs.

2. Immunohistochemistry: The mean number of cells CD68 (macrophages), CD57 (NK) and CD1a (dendritic cells) was $576.70 \pm 264.99 \mathrm{cell} / \mathrm{mm}^{2}, 12.45 \pm 9.52 \mathrm{cell} / \mathrm{mm}^{2}$ and $24.21 \pm 16.09 \mathrm{cell} / \mathrm{mm}^{2}$, respectively. Macrophage was the most common cell in the inflammatory infiltrate. The number of macrophages was higher than NK cells and dendritic cells $(p<0.001)$.

The number of cells expressing IL-1, IL-6, TNF- $\alpha$ and IFN- $\gamma$ are in the Figure 1. Among the cytokines studied, IFN- $\gamma$ was the most common expressed, showing $17.67 \pm 18.21$ cells $/ \mathrm{mm}^{2}$ with this cytokine. In the second place was IL- 6 with $13.30 \pm 13.72$ cells $/ \mathrm{mm}^{2}$, followed by TNF- $\alpha$ $\left(8.85 \pm 9.93\right.$ cells $\left./ \mathrm{mm}^{2}\right)$ and IL-1 $\left(8.44 \pm 9.78\right.$ cells $\left./ \mathrm{mm}^{2}\right)$.

The number of cells expressing TLR2 and TLR4 in patients with ATL was $145.48 \pm 82.46 \mathrm{cell} / \mathrm{mm}^{2}$ and $3.26 \pm 4.11 \mathrm{cell} / \mathrm{mm}^{2}$ respectively ( $p=0.0049$ ). The proportion of TLR2/TLR4 positive cells in the tissue was 44:1. The expression of TLR2 and TLR4 in the control group was $37.33 \pm 21.88 \mathrm{cell} / \mathrm{mm}^{2}$ and $10.00 \pm 2.77 \mathrm{cell} / \mathrm{mm}^{2}$, respectively.

The linear regression did not show association/correlation between the number of cells expressing cytokines with TLR2/TLR4. There was not linear association/correlation of number of specific cells (macrophages, NK cells and dendritic cells) with the number of cells expressing TLR2 or TLR4.

The double immunostaining showed that the expression of TLR2 occurred in macrophages (Fig. 2). Dendritic and NK cells did not express TLR2. The co-expression of TLR4 and other cellular phenotypes (CD68, CD57 and CD1a) was not determined by double immunostaining.

\section{DISCUSSION}

By immunohistochemistry, we observed that the expression of TLR2 was increased compared to normal skin. The expression of TLR2 was significantly higher than TLR4 in ATL. Furthermore, the expression of TLR4 was lower in ATL compared to normal skin. These data suggest

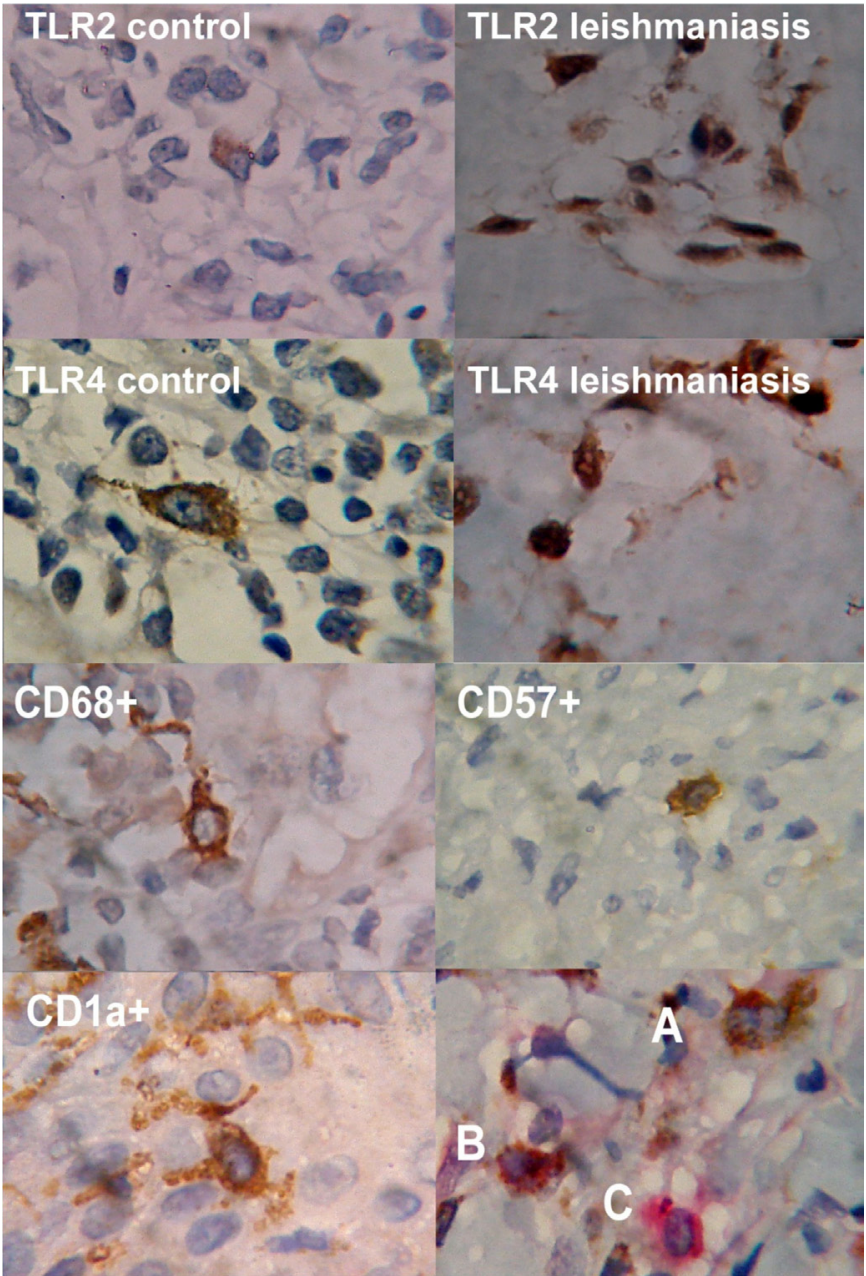

Fig. 2 - Immunohistochemistry pattern of TLR2 and TLR4 with other cellular phenotype (macrophage-cd68, KN cell - CD57 and dendritic cell - CD1a). In the final right square is the double immunohistochemistry showing macrophage expression of TLR2 (A and B), C represents a macrophage without TLR2 expression.

that TLR2 can be more important than TLR4 in the immune response of patients with ATL.

After recognition of specific antigens of Leishmania (glycoinositol 
TUON, F.F.; FERNANDES, E.R.; DUARTE, M.I.S. \& AMATO, V.S. - Expression of TLR2 and TLR4 in lesions of patients with tegumentary American leishmaniasis. Rev. Inst. Med. Trop. Sao Paulo, 54(3): 159-63, 2012.

phospholipids and lipophosphoglycans), TLR2 and TLR4 trigger NF- $\kappa B$, which, then, proceeds to the nucleus and promotes the transcription and further synthesis of proinflammatory cytokines.

All TLRs are expressed in macrophages in models of leishmaniasis after stimuli with IFN- $\gamma^{8}$, however, mRNA transcription of TLR2 is increased in the leishmaniasis when compared with other TLRs. Dendritic cells, macrophages and NK cells can express TLR2, as demonstrated in models of cutaneous leishmaniasis. In our study, TLR2 was expressed only by macrophage in the double immunostaining. Macrophage is the most important cell in the cutaneous leishmaniasis and several studies demonstrated that TLR2 is expressed at the surface of this cell ${ }^{6,8,12,13}$. The absence of TLR2 in other cells can be associated with the phase of the disease, because DC and NK cells decrease in this period of the leishmaniasis. The cytokines promotes an up-regulation of the TLR2 to maintain a continuous inflammatory response by unknown mechanism9 9 Our results are similar to those obtained in experimental models of $L$. major in mice ${ }^{4,6,8}$. Lipophosphoglycan, a polymer of repeating Gal $\beta 1-$ $4 \mathrm{Man} \alpha-\mathrm{PO}^{4}$ units and a prominent Leishmania surface glycoconjugate ${ }^{14}$, activates both mouse macrophages and human NK cells through TLR2 ${ }^{4,6}$. The binding of lipophosphoglycan to TLR2 enhances IFN- $\gamma$ and TNF- $\alpha$ production and nuclear translocation of NF- $\mathrm{KB}^{18}$. Cytokines expression was increased in our study, mainly IFN- $\gamma$ and IL-6. However, we cannot correlate the TLR2 expression with any cytokine evaluated.

During first studies, TLR4 was a promising signaling receptor for Leishmania $^{12}$. Nevertheless, further studies showed that TLR4 was less important than TLR2 and cytokine expression was independent of this receptor $^{2}$. KAVOOSI et al. demonstrated in two studies that TLR4 is not activated by Leishmania ${ }^{10,11}$. The importance of TLR4 could be related with an alternative activation through the neutrophil elastase in the first steps of cutaneous leishmaniasis ${ }^{15}$. Other TLRs have been associated with Leishmania infection. TLR9 is associated with the granuloma formation, which is expressed by macrophages ${ }^{22}$.

Our study was the first to report the immune response related with TLR2 and TLR4 with L. braziliensis. The clinical presentation of cutaneous leishmaniasis is related with Leishmania species. L. major is not found in America, but the immune response is similar to $L$. braziliensis. These data cannot be applied to L. amazonensis, whose immune response is predominantly Th $2^{19}$.

Our data provide additional support for the role of TLR2 in ATL. The in situ evaluation of TLR2 and TLR4 expression in the human ATL caused by L. braziliensis confirmed data from experimental studies with L. major. In a previous review about TLR and leishmaniasis we had compromised ourselves to show the in situ immune response of TLR in humans, to confirm data from in vitro studies ${ }^{18}$.

Our knowledge of the innate immune response improved rapidly over the last decade, and this has brought new therapeutic prospects to light, including the use of TLRs for immunotherapy or vaccine. We showed that the immune response and receptor expression of experimental models can be similar with that from human.

\section{AUTHOR CONTRIBUTIONS}

Felipe Francisco Tuon - Analysis of the immunohistochemistry, manuscript writing, statistical analysis. Elaine Ribeiro Fernandes -
Immunohistochemistry, manuscript review. Maria Irma Seixas Duarte - Immunohistochemistry review and diagnosis of patients. Valdir Sabbaga Amato - Manuscript writing and review.

\section{RESUMO}

\section{Expressão de TLR2 e TLR4 em lesões de pacientes com leishmaniose tegumentar americana}

Objetivos: O objetivo deste estudo foi descrever o padrão de expressão dos receptores toll-like 2 e 4 (TLR2 e TLR4) em biópsias de pele de pacientes com leishmaniose tegumentar americana (LTA). Métodos: Este estudo prospectivo avaliou 12 pacientes com LTA causada por Leishmania braziliensis confirmada por reação em cadeia da polimerase. Imunohistoquímica foi realizada para determinar a expressão de TLR2 e TLR4. O número de células NK, células dendríticas e macrófagos foi calculado no tecido. A expressão de citocinas foi determinada usando anti-TNF- $\alpha$, anti-IFN- $\gamma$, anti-IL-1 e anti-IL-6. Dupla marcação foi usada para determinar a célula responsável pela expressão de TLR2 e TLR4. Resultados: O número de células expressando TLR2 e TLR4 foi $145.48 \pm 82.46$ cell $/ \mathrm{mm}^{2}$ e $3.26 \pm 4.11$ cell $/ \mathrm{mm}^{2}$ respectivamente $(p<0.05)$. Não houve correlação entre a quantidade de expressão de TLR2 e TLR4 com a quantidade de citocinas e o número de células NK, macrófagos e células dendríticas. A dupla marcação revelou que o TLR2 é expresso por macrófagos. Conclusão: Na LTA causada por Leishmania braziliensis, TLR2 é o TLR mais comum na doença ativa, principalmente por macrófagos sem correlação com a quantidade de citocinas e outras células.

\section{ACKNOWLEDGMENTS}

We thank Heitor Andrade for polyclonal antibodies to Leishmania, Helio Bacha for PCR methods, Ricardo Zampiere and Maria Lucile for PCR used in the species determination, Fernanda Guedes for TLR tests in cutaneous diseases and control cases.

\section{REFERENCES}

1. Amato VS, Tuon FF, de Andrade HF, et al. Immunohistochemistry and polymerase chain reaction on paraffin-embedded material improve the diagnosis of cutaneous leishmaniasis in the Amazon region. Int J Dermatol. 2009;48:1091-5.

2. Antoniazi S, Price HP, Kropf P, Freudenberg MA, Galanos C, Smith DF, et al. Chemokine gene expression in toll-like receptor-competent and -deficient mice infected with Leishmania major. Infect Immun. 2004;72:5168-74.

3. Barton GM, Medzhitov R. Toll-like receptor signaling pathways. Science. 2003;300:1524 5 .

4. Becker I, Salaiza N, Aguirre M, Delgado J, Carrillo-Carrasco N, Kobels LG, et al. Leishmania lipophosphoglycan (LPG) activates NK cells through toll-like receptor-2. Mol Biochem Parasitol. 2003;130:65-74.

5. Castilho TM, Camargo LM, McMahon-Pratt D, Shaw JJ, Floeter-Winter LM. A real-time polymerase chain reaction assay for the identification and quantification of American Leishmania species on the basis of glucose-6-phosphate dehydrogenase. Am J Trop Med Hyg. 2008;78:122-32.

6. de Veer MJ, Curtis JM, Baldwin TM, Di Donato JA, Sexton A, McConville MJ, et al. MyD88 is essential for clearance of Leishmania major: possible role for lipophosphoglycan and Toll-like receptor 2 signaling. Eur J Immunol. 2003;33:282231. 

Sao Paulo, 54(3): 159-63, 2012.

7. Duarte MI, Tuon FF, Pagliari C, Kauffman MR, Brasil RA. Human visceral leishmaniasis expresses Th1 pattern in situ liver lesions. J Infect. 2008;57:332-7.

8. Flandin JF, Chano F, Descoteaux A. RNA interference reveals a role for TLR2 and TLR3 in the recognition of Leishmania donovani promastigotes by interferon-gamma-primed macrophages. Eur J Immunol. 2006;36:411-20.

9. Hernandez JC, Stevenson M, Latz E, Urcuqui-Inchima S. HIV type 1 infection upregulates TLR2 and TLR4 expression and function in vivo and in vitro. AIDS Res Hum Retroviruses. 2012. (Epub ahead of print)

10. Kavoosi G, Ardestani SK, Kariminia A. The involvement of TLR2 in cytokine and reactive oxygen species (ROS) production by PBMCs in response to Leishmania major phosphoglycans (PGs). Parasitology. 2009;136:1193-9.

11. Kavoosi G, Ardestani SK, Kariminia A, Alimohammadian MH. Leishmania major lipophosphoglycan: discrepancy in toll-like receptor signaling. Exp Parasitol. 2010;124:214-8

12. Kropf P, Freudenberg MA, Modolell M, Price HP, Herath S, Antoniazi S, et al. Toll-like receptor 4 contributes to efficient control of infection with the protozoan parasite Leishmania major. Infect Immun. 2004;72:1920-8.

13. Kropf P, Freudenberg N, Kalis C, Modolell M, Herath S, Galanos C, et al. Infection of $\mathrm{C} 57 \mathrm{BL} / 10 \mathrm{ScCr}$ and $\mathrm{C} 57 \mathrm{BL} / 10 \mathrm{ScNCr}$ mice with Leishmania major reveals a role for Toll-like receptor 4 in the control of parasite replication. J Leukoc Biol. 2004;76:4857.

14. McConville MJ, Ferguson MA. The structure, biosynthesis and function of glycosylated phosphatidylinositols in the parasitic protozoa and higher eukaryotes. Biochem J. 1993;294:305-24.

15. Ribeiro-Gomes FL, Moniz-de-Souza MC, Alexandre-Moreira MS, Dias WB, Lopes MF, Nunes MP, et al. Neutrophils activate macrophages for intracellular killing of Leishmania major through recruitment of TLR4 by neutrophil elastase. J Immunol. 2007;179:3988-94
16. Schwartz E, Hatz C, Blum J. New world cutaneous leishmaniasis in travellers. Lancet Infect Dis. 2006;6:342-9.

17. Tuon FF, Amato VS. Neglected tropical diseases: beyond the wars. Rev Inst Med Trop Sao Paulo. 2008;50:313-4.

18. Tuon FF, Amato VS, Bacha HA, Almusawi T, Duarte MI, Amato Neto, V. Toll-like receptors and leishmaniasis. Infect Immun. 2008;76:866-72.

19. Tuon FF, Amato VS, Floeter-Winter LM , de Andrade Zampieri R, Amato Neto V, Siqueira França FO, et al. Cutaneous leishmaniasis reactivation 2 years after treatment caused by systemic corticosteroids - first report. Int J Dermatol. 2007;46:628-30.

20. Tuon FF, Duarte MI, Amato VS. A quantitative and morphometric study of mast cells in cutaneous leishmaniasis. Parasite Immunol. 2008;30:641-5.

21. Tuon FF, Fernandes ER, Duarte MI, Amato VS. The expression of TLR2, TLR4 and TLR9 in the epidermis of patients with cutaneous leishmaniasis. J Dermatol Sci. 2010;59:55-7.

22. Tuon FF, Fernandes ER, Pagliari C, Duarte MI, Amato VS. The expression of TLR9 in human cutaneous leishmaniasis is associated with granuloma. Parasite Immunol. 2010;32:769-72.

23. Tuon FF, Gomes-Silva A, Da-Cruz AM, Duarte MI, Neto VA, Amato VS. Loca immunological factors associated with recurrence of mucosal leishmaniasis. Clin Immunol. 2008;128:442-6.

24. Tuon FF, Guedes F, Fernandes ER, Pagliari C, Amato VS, Seixas Duarte MI. In situ immune responses to interstitial pneumonitis in human visceral leishmaniasis. Parasite Immunol. 2009;31:98-103.

Received: 16 December 2011

Accepted: 4 April 2012 


\section{LIBRARY OF THE SÃO PAULO INSTITUTE OF TROPICAL MEDICINE}

Website: www.imt.usp.br/portal

Address: Biblioteca do Instituto de Medicina Tropical de São Paulo da Universidade de São Paulo Av. Dr. Enéas de Carvalho Aguiar, 470. Prédio 1 - Andar térreo.

05403-000 São Paulo, SP, Brazil.

Telephone: 5511 3061-7003 - Fax: 5511 3062-2174

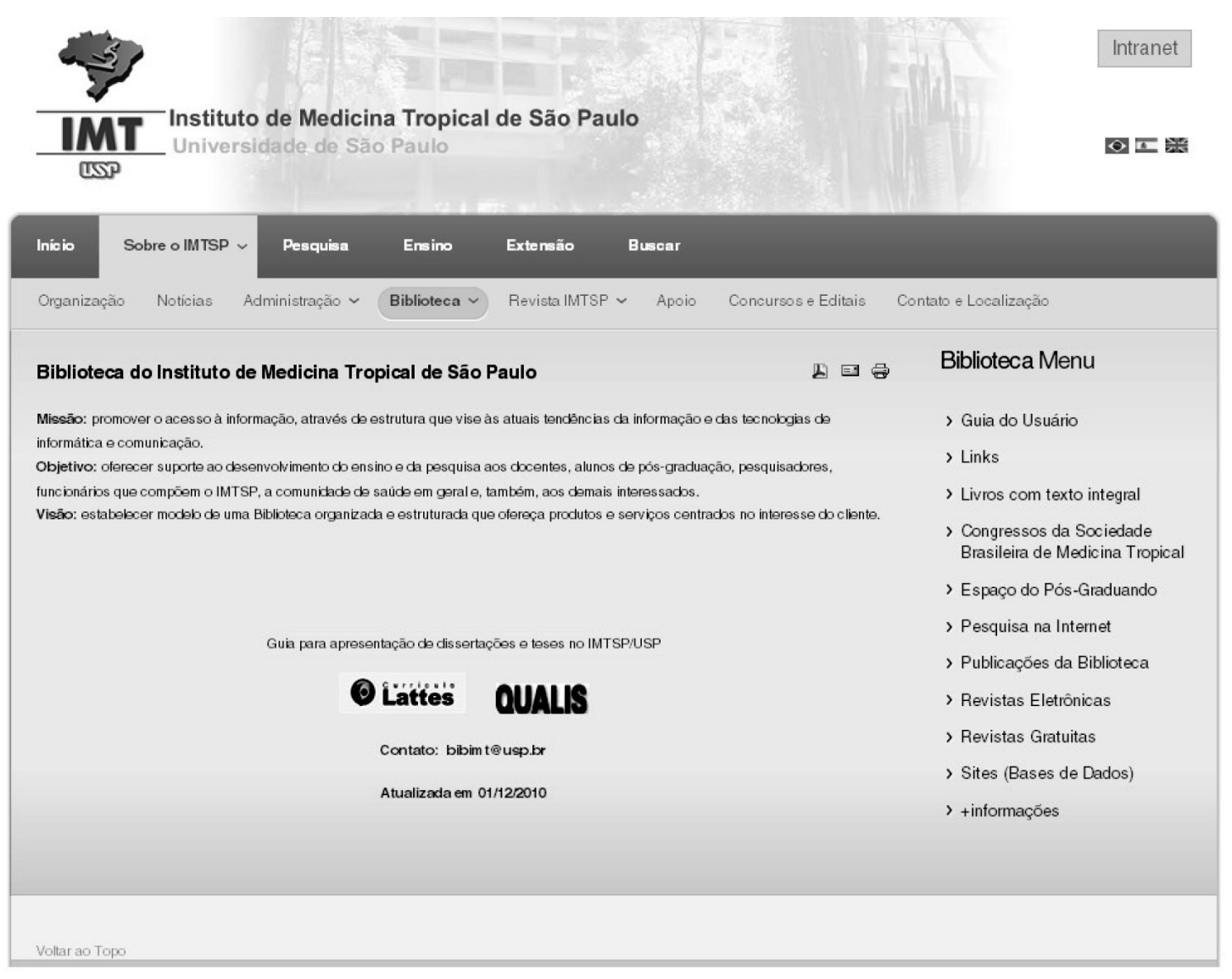

The Library of the São Paulo Institute of Tropical Medicine (IMTSP Library) was created on January 15,1959 in order to serve all those who are interested in tropical diseases. To reach this objective, we select and acquire by donation and / or exchange appropriate material to be used by researchers and we maintain interchange between Institutions thorough the Journal of the São Paulo Institute of Tropical Medicine, since the Library has no funds to build its own patrimony.

The IMTSP Library has a patrimony consisting of books, theses, annals of congresses, journals, and reference works.

The collection fo journals existing in the Library can be verified through the USP - Bibliographic Database - OPAC - DEDALUS http://dedalus.usp.br:4500/ALEPH/eng/USP/USP/DEDALUS/start of the USP network. 